\title{
Digitally-Powered Human Resource Management: Skills and Roles in the Digital Era
}

\author{
Anastasiia Mazurchenko ${ }^{1}$, Kateřina Maršíková ${ }^{1}$
}

\begin{abstract}
Digitalization in human resource management helps enterprises to modernize HR functions and provides them with a competitive advantage. At the same time, it requires a change in working style and entails a change in the demand for HR competencies. The purpose of this paper is to introduce the phenomenon of digitalization in the literature, explore its current key benefits and risks, and analyse its influence on HR professionals' competencies and roles. The qualitative research includes an analysis of the secondary data describing the existing level of digital skills based on the reactions of more than 7,000 respondents from six EU member states (Germany, Finland, United Kingdom, Portugal, Sweden, and Slovakia). The primary data analysis concerning HR social media competencies collected in five European countries which participated in the SHARPEN project is also presented here. The current trends in HR professional competencies are also described in this paper. The results obtained show that HR professionals tend to be slightly reluctant to adopt technology. The results also confirmed the importance of digitalization for human resources and the increasing demand for digital skills in recent years.
\end{abstract}

Keywords: Digital Technology, HR Automation, ICT Competencies, Fourth Industrial Revolution, Human Resource Specialist.

\section{Introduction}

The global phenomenon of digitalization and robotization has a significant impact on the world of work and job markets. Today's enterprises are forced to deal with the constant flow of new technologies and information, new employment forms, fast digitalization of the workplace and changing demand for employees' skills that encourages them to rethink the way they manage a workforce. In this case, HR functions play an essential role in leading changes and adding strategic value to the company in the digital era (Bokelberg et al., 2017). HR might provide help for employees by assisting their career building and also for companies by drawing attention to the benefits which new digital technologies offer (Mitrofanova et al., 2019). Overall, basic digital skills are seen as at least somewhat important for almost all the jobs (Curtarelli et al., 2016).

The rapid advancement of digital technologies, such as artificial intelligence, cloud computing, Big Data, robot process automation, social media, real-time communication and an increasing use of virtual reality, is bringing a new functionality to the HR department. As a result, digital transformation influences the way HR functions are fulfilled through using digital tools and apps to innovate processes, make decisions and solve problems (Manuti \& de

\footnotetext{
${ }^{1}$ Faculty of Economics, Technical University of Liberec, Voroněžská 13, 46001 Liberec 1, Czech Republic

$\bowtie$ anastasiia.mazurchenko@tul.cz
} 
Palma, 2018, pp. 41-44). Digitalization requires redesigning the role of HR professionals and developing new competencies that will help to ensure employee wellbeing and organizational sustainability in the digital era (Cantoni \& Mangia, 2019, pp. 58-59).

The paper aims to introduce aspects of digitalization and robotization in the work of HR practitioners, identify positive and negative aspects of this phenomenon, and the challenges for HR created by new digital technologies. The authors introduce several selected findings concerning the influence of digitalization on HR competencies and future HR roles. A theoretical literature review as well as secondary data analysis map the topic of skills and roles of HR specialists in the digital era.

The paper is structured as follows. The literature review describes the main challenges and opportunities for HRM created by digitalization and robotization. The next chapter summarizes the merits and demerits of technologies in HR. Then there is a chapter devoted to traditional and digital HR competencies and roles. The secondary data analysis in the chapter shows the influence of digitalization on key HR professionals' competencies and skills. Current trends in digitalization in HR specialist positions are based on data from the European Digital Skills Survey and data collected in 2018 in five European regions in SMEs. This section is followed by a discussion of findings from previous studies about digital transformation in HR, and the limitations of this study that set the direction for further research.

It should be mentioned here that this article is an extension of considerations and discussions undertaken within the paper that was presented by the authors at 14th International Conference Liberec Economic Forum (LEF 2019) at the Technical University of Liberec (Maršíková \& Mazurchenko, 2019).

\section{$1.1 \quad$ Literature Review}

The first mention of the term digitalization is attributed to Robert Wachal, who used it in the sense of «digitalization of society» in 1971 and explained its origin as the result of a more widespread use of digital technologies (Pieriegud, 2016). According to Kagermann (2015) digitalization may be defined as the networking of people and things and the convergence of the real and virtual worlds that are enabled by ICT. Brennen and Kreiss (2016, pp. 556-566) point out that digitalization is based on the adoption or increase in the use of digital or computer technology by an organization, industry, country, etc. As a result, ICT has caused the restructuring of many areas of social life. Molotkova et al. (2019) in their research highlight the goals that companies aim to achieve through active utilization of digital technologies. They include increasing the quality of the company's products or services and an intensification of communication both within the company and with its customers for higher business efficiency.

Digital transformation is becoming a hot topic for companies worldwide. DiRomualdo et al. (2018) consider digital transformation to be the enabler of fundamental changes in the ways a company delivers its products and services, of an improvement in interaction with stakeholders, and of creating business value by utilizing digital technologies. In other research, it is emphasized that digital transformation is closely connected with changing the expectations of employees, customers and business partners, and with conditions for running a business under the influence of technologies (Oracle \& Research Now SSI, 2018). Fenech et al. (2019) claim that digital transformation results in changes of business structures, processes and operations by utilizing the benefits of new technologies. It should also be noted that digital transformation as a digital evolution of a company's business model and its process of 
formulating ideas or methodology takes place on two levels: strategical and tactical (Mazzone, 2014, pp. 8-10).

The need to adapt to the new conditions of the global business environment and the growth of digital innovation leads to the fact that companies are forced to modify or completely change ways of working and then reshape their business model. The implementation of integrated strategies that focus on finding new talents, professional development and retention of current employees in the company is crucial to the success of the digital transformation of human resources. In this sense, HR are becoming a strategic partner of the company to ensure a long-term competitive advantage of the company in the era of digitalization (Ulrich \& Dulebohn, 2015).

The term digital $H R$ can be understood as integrating social, mobile, analytics and cloud (SMAC) technologies aimed at automating different areas of HR for better productivity, redefining how HR processes are delivered, and improving work-life balance focusing on real-time access, decision-making and results (Stephan et al., 2016). The main idea behind this concept is to modernize employee training and skill development, searching for talents, and to streamline overall human resources management solutions and functions by utilizing real-time interactive platforms, mobile-first apps, and integrated analytics (Galgali, 2017). Molotkova et al. (2019) identify digital HR as a flexible approach to staff development with an active role of digital space in stimulating changes and an effective use of employees' talents and experience. Contrary to traditional personnel management, digital HR are focused on the implementation of innovative solutions, personnel productivity improvement and it perceives employees as investments that should be supported.

The emergence of the digital HR concept is the result of fundamental changes in the approach to HRM over the years. In the 60s and 70s, the main goal of HR managers was to process and analyse employee information and automate their daily activities. In the 80s, personnel departments started to provide professional consultancy and react to the needs of individual employees. From the early $90 \mathrm{~s}$ to the beginning of the $21^{\text {st }}$ century, HR functions have focused on talent management and the implementation of new electronic systems to support recruitment, learning, performance management and employee remuneration (Volini et al., 2017). In the $21^{\text {st }}$ century, HR have been able to revolutionize the experience of employees by the transformation of HR processes through the use of new digital platforms, applications, and methods of providing HR services including digital communication (Stephan et al., 2016).

\subsection{Merits and Demerits of Technologies in HR}

HR specialists as well as whole organizations are faced with the merits and demerits of using technologies in HR. Some of these are often mentioned as benefits but can also be considered potential risks. The following Tab.1 shows both the benefits and the risks of digitalization for HR:

\begin{tabular}{|l|l|}
\hline Benefits (merits) of digitalization in HR & Risks (demerits) of digitalization in HR \\
\hline Better quality with fewer human errors & $\begin{array}{l}\text { Employees' unwillingness to embrace new } \\
\text { technologies (resistance to change) }\end{array}$ \\
\hline Increased operational efficiency & Replacement by automation \\
\hline Cuts in HR costs & Cyberattacks (personal information leakage) \\
\hline Speeding up HRM processes & Data security \\
\hline
\end{tabular}




\begin{tabular}{|l|l|}
\hline $\begin{array}{l}\text { Data security, improving the decision-making } \\
\text { process }\end{array}$ & $\begin{array}{l}\text { Changing business model, organizational structure, } \\
\text { employee-employer relations }\end{array}$ \\
\hline Reliability and transparency of data & Data integration of separate IT systems \\
\hline Improving the overall employee experience & Digital tools available for HR still not fully utilized \\
\hline Driving business growth (competitiveness) & Slow transformation of HR competencies \\
\hline $\begin{array}{l}\text { Empowerment of the HR department (role of a } \\
\text { strategic business partner) }\end{array}$ & $\begin{array}{l}\text { Lack of investment in training to support HR digital } \\
\text { skills }\end{array}$ \\
\hline Embracing the digital talent lifecycle & \\
\hline
\end{tabular}

Tab. 1. Key benefits and risks of digitalization in HR. Source: Authors based on (Mangipudi \& Vaidya, 2018; Bokelberg et al., 2017; Paychex, 2018; Velthuijsen et al., 2017).

HR departments have a strategic value added in the role of understanding the challenges companies face in connection with Industry 4.0, helping to identify which staff could be affected by automation and create a culture in which work is subject to change. Together with new technologies HR professionals more often face large volumes of data in different spreadsheets, a lack of functionality of IT systems and insufficient user experience, which has brought about challenges in recruiting, retaining and engaging employees (see Tab.2). Radical changes caused by new technologies and innovations like big data and analytics, autonomous robots, the Internet of Things, clouds, virtual reality, and artificial intelligence, lead to the need for up-skilling or re-skilling employees. It is worth noting that such competencies as emotional intelligence, creativity, cognitive flexibility and managing others are not likely to be executed by devices and machines. This emphasizes the importance of attracting an agile workforce to current organizations that will be active, adaptable and able to quickly accept new ideas and responsibilities (Cantoni \& Mangia, 2019, pp. 232-235). Therefore, digitalization has to be strongly connected with an organization's HR strategy, as employees' personality, soft skills and attitude to work cannot be analyzed and evaluated by digitalized systems and devices (Mangipudi \& Vaidya, 2018).

\begin{tabular}{|l|l|}
\hline \multicolumn{1}{|c|}{ Processes in HRM } & \multicolumn{1}{|c|}{ Challenges for HR managers caused by Industry 4.0 } \\
\hline Human resource planning & $\begin{array}{l}\text { Developing a new staff planning strategy concerned with redesigning job } \\
\text { profiles, redistribution of workforce and new requirements in terms of } \\
\text { problem-solving, human-machine interaction and digital competencies }\end{array}$ \\
\hline Recruitment & $\begin{array}{l}\text { Difficulties with sourcing employees and senior executives who can } \\
\text { effectively manage change }\end{array}$ \\
\cline { 2 - 3 } & $\begin{array}{l}\text { The necessity of changing the approach to recruiting by focusing more on } \\
\text { competencies than on qualifications }\end{array}$ \\
\hline Learning and development & $\begin{array}{l}\text { Addressing potential skill gaps within the workforce due to automation and the } \\
\text { decreasing value of formal degrees and training }\end{array}$ \\
\cline { 2 - 3 } & $\begin{array}{l}\text { The necessity of developing a new organizational mindset and cognitive } \\
\text { readiness skills such as mental cognition, attentional control, sense-making, } \\
\text { intuition, problem solving, adaptability and communication, in order to be } \\
\text { ready for the dynamic digital business environment }\end{array}$ \\
\cline { 2 - 2 } & $\begin{array}{l}\text { The ubiquitous use of e-learning with orientation on design thinking and } \\
\text { digital talents development }\end{array}$ \\
\hline
\end{tabular}




\begin{tabular}{|l|l|}
\hline \multirow{2}{*}{ Performance management } & $\begin{array}{l}\text { Implementation of the mentoring and feedback processes which rely on digital } \\
\text { technologies and require advanced ICT skills }\end{array}$ \\
\cline { 2 - 2 } & $\begin{array}{l}\text { Greater social responsibility required from the HR department in case of such } \\
\text { potential work drawbacks as stress, work-life imbalance, and work insecurity }\end{array}$ \\
\hline Retention & Minimizing attrition of high-skilled workers \\
\cline { 2 - 2 } & $\begin{array}{l}\text { Ensuring efficient communication and development opportunities for the } \\
\text { talents, qualifying them for more complicated jobs and tasks }\end{array}$ \\
\hline
\end{tabular}

Tab. 2. Challenges created by Industry 4.0 in HR. Source: Authors based on (Cantoni \&Mangia, 2019, pp.59-62; Mitrofanova et al., 2019; Sorko et al., 2016; Molotkova et. al, 2019).

One of the HRM processes that are influenced by technologies is recruitment. As Böhmová and Chudán (2018) point out, in recruitment social media networks offer a solution that is innovative and potentially cost-effective. Social media networks are a virtual space with a huge potential as it is a space where people voluntarily share personal information, which can be used as a way to contact them (Böhmová \& Chudán, 2018). People using social media in recruitment need to have social media awareness including the knowledge of how to use and analyse the data they get, and to understand the principles of social media network and communication.

\subsection{Traditional versus digital HR competencies and roles}

It is important to emphasize that current competencies and roles of $\mathrm{HR}$ are no longer sufficient and do not correspond to their changing responsibilities. Rastgoo (2016) in his study identifies human resource competencies as personal characteristics and measurable abilities of HR professionals which allow them to perform well in their role and achieve high performance. It has also been argued that knowledge, attitude, skills and characteristics are among the main parameters of human resource competencies. Stracke (2011) in his study of competencies and skills in the digital era draws attention to the fact that competencies cannot be observed directly but can only be measured by action aimed at achieving specific objectives. Another study (Lo et al., 2015) emphasizes the distinction between strategic HR competencies, which include business knowledge and active involvement in strategic decision-making, and functional HR competencies related to the delivery of HR operations, personal credibility and active use of HR technologies.

The ongoing development of HR technologies creates new tasks and roles for HR professionals and motivates them to develop strong HR technology competencies. Tab. 3 shows the evolution of human resources competencies, which under the influence of digitalization shift from traditional to digital HR competencies and technical skills.

\begin{tabular}{|l|l|}
\hline Traditional HR competencies & Key Digital HR competencies \\
\hline Relationship management (consultation) & Digital literacy \\
\hline Ethical practice & Digital communication (social media) \\
\hline Business acumen & Data analytics and cloud technologies \\
\hline HR expert knowledge & Dealing with complexity (multitasking) \\
\hline
\end{tabular}




\begin{tabular}{|l|l|}
\hline Workforce planning and change management & Working in an agile way, creativity \\
\hline Diversity management, cultural awareness & Lifelong learning (skills development) \\
\hline Critical thinking & Problem-solving (digital solutions) \\
\hline
\end{tabular}

Tab. 3. Traditional HR competencies versus digital HR competencies. Source: Authors based on (European Round Table of Industrialists, 2017; SHRM, 2012).

The results of seven research studies, carried out since 1987 and involving interviewing around 100,000 respondents, were provided by Ulrich et al. and confirmed that key HR competencies are associated with environmental requirements and they change over time. The latest study (2016) with over 31,000 HR participants from all over the world identified nine new core competencies that are critical to the development of HR specialists in the digital era. These competency domains include Paradox Navigator, Human Capital Curator, Total Rewards Steward, Credible Activist, Culture and Change Champion, Strategic Positioner, Compliance Manager, Analytics Designer and Interpreter, Technology and Media Integrator. One of Ulrich et al.'s (2016) key findings is that HR professionals are seen as having less competence in Technology and Media Integrator, which may indicate the relative newness of this competency domain.

In contrast to Ulrich's model, Crummenerl et al. (2018) identify five potential roles of HR designed to meet the challenges of automation and digital transformation within organizations. They are represented by Network Connector, Agile Enabler, Innovation Architect, Data Analyst, and Digital Consultant. Every fifth interviewed HR expert considers the roles of Data Analyst and Digital Consultant important for the future of HR in the first place. This is due to the possibilities of automation of administrative tasks, faster decision-making based on transparent data and increasing the availability of employee self-service tools. The study also shows that the described roles must be developed taking into account not only the strategic orientation and specific context of the organization but also the individual characteristics of its employees.

Accenture survey (2017) of HR transformation focused on three emerging HR roles that will be crucial in future and will demand a radical change of HR leaders' competencies. HR professionals in the role of Social Integrator will need to be able to act as unifiers and social listeners, providing personalized empathic approaches, mentor programs and understanding the life priorities of their employees. The main tasks of the Talent Intelligence Advocate will be mastering analytics capabilities for proactive sourcing of candidates, building valuable relations with digital talents and tracking their movement across geographies, industries and workforce types based on their online profiles. The role of the Strategic HR Business partner will be connected with the necessity of demonstrating a broad business perspective and strategic mindset, digital communication skills and result-focused approach.

From the analysis of the literature, it is possible to identify the changes in the role of HR professionals caused by digital disruption. It appears that HR professionals need to be digital-ready to strengthen their position in business and revolutionise employee experience by incorporating people, HR technologies and processes in a new digital ecosystem. It means being prepared to embrace digital technologies and having the necessary awareness, skills, and resources to use them to meet current employee expectations, improve business flexibility and increase its efficiency (Patmore et al., 2017). 


\section{Research methods}

The main focus of the paper is to identify the current trends in human resource management caused by digitalization and their impact on required HR specialist skills. The research questions focus on: "How do digital tools and technologies influence the way HR functions are implemented?", "What are the benefits and risks of using technologies in HR?" and "Which roles and competencies of HR professionals will be the most important in the digital era?". The paper meets this need by providing qualitative and quantitative research results based on secondary data obtained by the following methods: systematic review and content analysis of scientific literature, secondary data analysis based on expert assessment and forecasting, and the use of systematic approach.

Secondary data from the literature review and the database of the European Commission were used for the data analysis in this paper. As well as primary data collected within the surveys SHARPEN related to the issue of human resource management in SMEs was also used in this paper. In the first phase, keywords such as digital technology, ICT competencies, Fourth Industrial Revolution were used to gather materials for further analysis in academic databases Scopus, Web of Science, SpringerLink and Science Direct. The choice of sources of data was motivated by their reliability and high quality of research.

In the second stage authors analysed secondary data from the following sources:

- the database of the European Commission,

- surveys of multinational professional services networks (PwC, Deloitte, EY, etc.)

- studies and reports of management consulting firms (Capgemini, McKinsey, etc.).

The use of social media in recruitment as an important phenomenon of digitalization of HR activities is introduced on partial primary results in selected countries in Europe. These findings came from a survey carried out within a SHARPEN project in 2018, in which one of the authors of the paper participated. This survey analysed more than 400 respondents (SMEs) from 5 selected European regions in the Czech Republic, Finland, UK, Lithuania and Germany. All results presented in the paper support a better understanding of the experience and progress in the area of digitalization of human resource management practices in enterprises worldwide.

\section{Results of the research}

Certainly, digitalization causes changes in the structure of employment, ways of working and a company's expectations of employees' skill sets, which creates a need for skill revolution. As it was pointed out by the PwC study, around 5\% of UK jobs will be in the field of artificial intelligence, robotics or new appearing technologies by the 2030s. At the same time, the McKinsey Global Institute research (2017) underlines that under the influence of automation, artificial intelligence and digitalization $14 \%$ of the global workforce will probably be forced to develop new skills and change their occupational categories by 2030. Therefore, the role of HR becomes crucial for encouraging workers' new behaviour, identifying skills gaps and retraining talents in rapidly changing technology landscape. Correspondingly, HR has to be creative, innovative and technology-savvy to improve employees' experience and business outcomes (Velthuijsen et al., 2017). 


\subsection{The influence of digitalization on key HR professionals' competencies and skills: secondary data analysis}

Paychex Pulse of HR Survey (2018) revealed that using digital technologies by HR managers is helpful not only for improving recruiting and regulatory compliance, but it also allows them to play a strategic role in the decision-making process and company's success in general (Paychex, 2018). In the survey conducted by Oracle and Research Now SSI in nine countries across Europe, Australia, North and Latin America in 2018, HR professionals were asked to specify the main reasons why digital transformation helps HR to become more strategic and valuable for business. According to the opinion of the respondents, the reasons include providing more support to executive managers (37\%), agility and change in management leadership (32\%), and unlocking existing talents (29\%).

In the study by Patmore et al. (2017), 268 UK HR professionals were questioned about technology readiness, digital mind-set and their level of digital skills. The results show that only one in seven respondents identified their HR team as an expert one across a range of digital skills in the area of social media, mobile, analytics, data, digital learning, and user experience. This emphasizes that the majority ( $61 \%$ poor to average) has digital skills gaps, using digital analytics is the biggest of them (Patmore et al., 2017).

The study provided by Infocorp at the request of ManpowerGroup in 2017 examined the influence of automation on workforce by surveying around 20,000 employers in 42 countries. This study found that employers worldwide face challenges in looking for people with mixed soft, technical and digital skills, which allows reducing the risk of replacement by automation. Another relevant point is that more than half of the companies indicated communication, problem solving and organization as the HR specialists' soft skills that are the hardest to find in the digital era (ManpowerGroup, 2017). Besides, DiRomualdo et al. (2018) point out that employers have difficulties with hiring HR professionals with HR expertise, strategic thinking and business management skills. For this reason, the mismatch between current competencies and the new working conditions should be addressed by informal coaching and on-the-job training.

The Global Leadership Forecast released by DDI, the Conference Board and Ernst \& Young in 2018 focused on the state and context of the future of leadership. The survey was based on data integrated from 25, 812 leaders and 2,547 HR professionals from 54 countries. According to this report new business models, organizational structures, analytics and digital disruption influence the HR professionals' roles and actions to build their competences and credibility. The evidence suggests that about $70 \%$ of HR specialists see the need to increase the application of HR technology and analytic skills. Moreover, only $16 \%$ of HR leaders felt well prepared for operating in a highly digital environment (Wellins \& Sadjady, 2018).

\subsection{Trends of digitalization of HR: European Digital Skills Survey}

Based on the European Digital Skills Survey carried out among a representative sample of 7,800 workplaces in six EU member states (Germany, Finland, United Kingdom, Portugal, Sweden and Slovakia), there can be identified some trends in digitalization in the positions of HR specialists. Despite the fact HR managers were not mainly in the position of respondents in this survey, several questions indicated some findings of the influence of digitalization on HR ICT competencies. There were identified findings shown in the Tab. 4. Human resource managers belong to the occupations which were selected as the most important for day-to-day operations by sector, by type and level of digital skills of employees in selected jobs. However, only basic digital skills of HR managers were identified as essential, compared with 
all other positions listed below in which some level of advanced or specific digital skills is also needed.

\begin{tabular}{|c|c|c|c|c|c|}
\hline Sector & Rank & Job title & $\begin{array}{c}\text { Basic } \\
\text { digital } \\
\text { skills }\end{array}$ & $\begin{array}{c}\text { Advanced } \\
\text { digital } \\
\text { skills }\end{array}$ & $\begin{array}{c}\text { Specialist } \\
\text { digital } \\
\text { skills }\end{array}$ \\
\hline \multirow{10}{*}{$\begin{array}{l}\text { Information and } \\
\text { communication; } \\
\text { Professional, } \\
\text { scientific and } \\
\text { technical } \\
\text { activities; } \\
\text { Administrative } \\
\text { services }\end{array}$} & 1 & $\begin{array}{l}\text { Managing directors and chief } \\
\text { executives }\end{array}$ & 4 & 2 & 2 \\
\hline & 2 & $\begin{array}{l}\text { Clerical support workers not classified } \\
\text { elsewhere }\end{array}$ & 4 & 1 & 2 \\
\hline & 3 & Sales and marketing managers & 4 & 2 & 2 \\
\hline & 4 & Accountants & 4 & 2 & 2 \\
\hline & 5 & $\begin{array}{l}\text { Information and communication } \\
\text { technology service managers }\end{array}$ & 4 & 4 & 2 \\
\hline & 6 & General office clerks & 4 & 1 & 2 \\
\hline & 7 & Finance managers & 5 & 2 & 2 \\
\hline & 8 & $\begin{array}{l}\text { Engineering professionals not } \\
\text { classified elsewhere }\end{array}$ & 4 & 3 & 2 \\
\hline & 9 & Software developers & 4 & 4 & 2 \\
\hline & 10 & Human resource managers & 5 & 1 & 1 \\
\hline
\end{tabular}

Tab. 4. Occupations selected as the most important for day-to-day operations by sector and by type and level of digital skills of employees in selected jobs. Source: Authors based on (Curtarelli et al., 2016).

Note: 1 means not important at all, 5 means essential.

As findings from this survey confirm, these workplaces are more likely to expect further changes brought by digital technologies in all the selected jobs. From 6,264 valid responses in the next question, the digital skills that are the most important for HR managers were identified. Figure 1 introduces key digital skills for HR managers and software developers (where 5 means essential and 1 not important at all). As Figure 1 shows, using a word processor, creating spreadsheets, using the internet and e-mail are among HR managers' essential digital competencies. Also, social media and video calls were identified as very important. It should be noted that some level of programming is starting to have importance for HR managers. For comparison, authors selected software developers from the same sector of Information and communication, professional, scientific and technical activities. For software developers, using software and programming is also essential. 


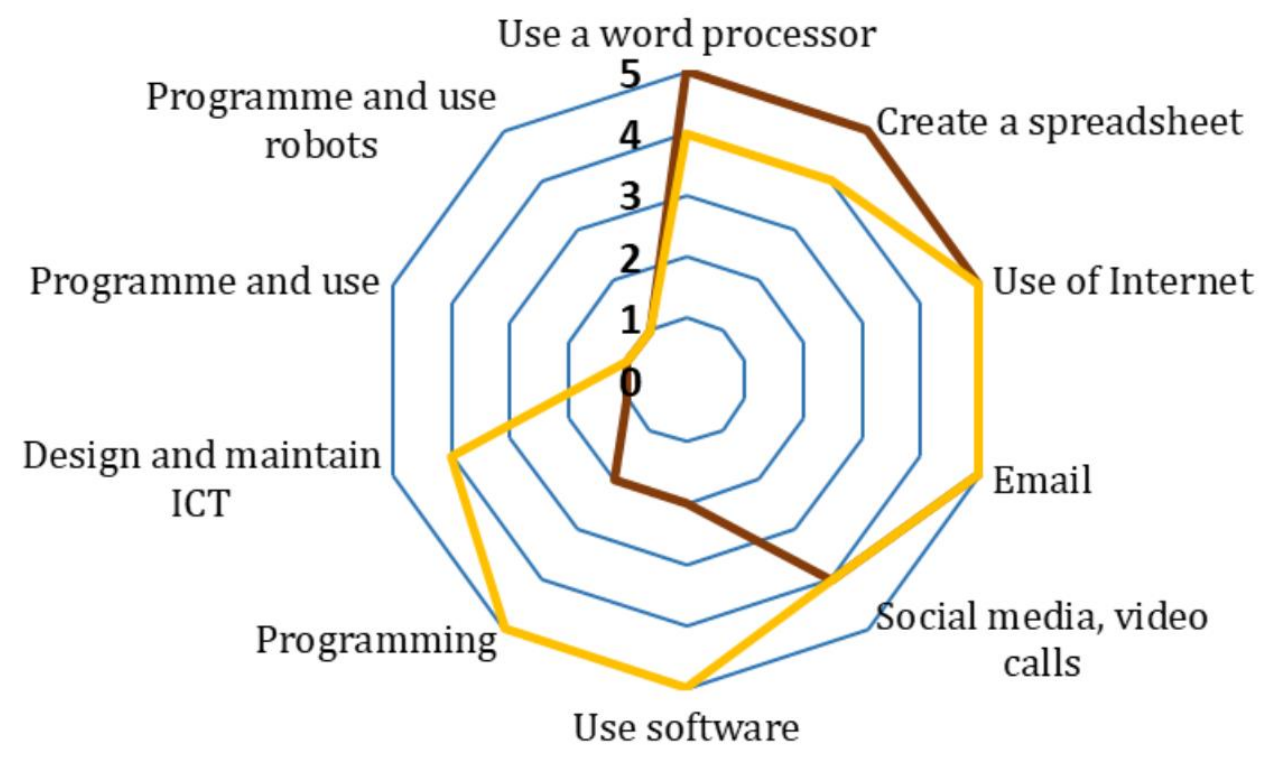

—Human resource managers

- Software developers

Fig. 1. Comparison of the importance of digital skills in selected jobs. Source: Authors based on (Curtarelli et al., 2016).

Social media competencies were identified as important to the HR manager. They are often used in recruitment (as mentioned above). It is interesting to see how social media are now also becoming important for enterprises (namely SMEs). The data collected in 2018 in five European regions in SMEs show that using social media for recruitment is not seen by SMEs as important. The following figure shows how many $\%$ of respondents in this survey confirmed using social media for recruitment (see Fig. 2).

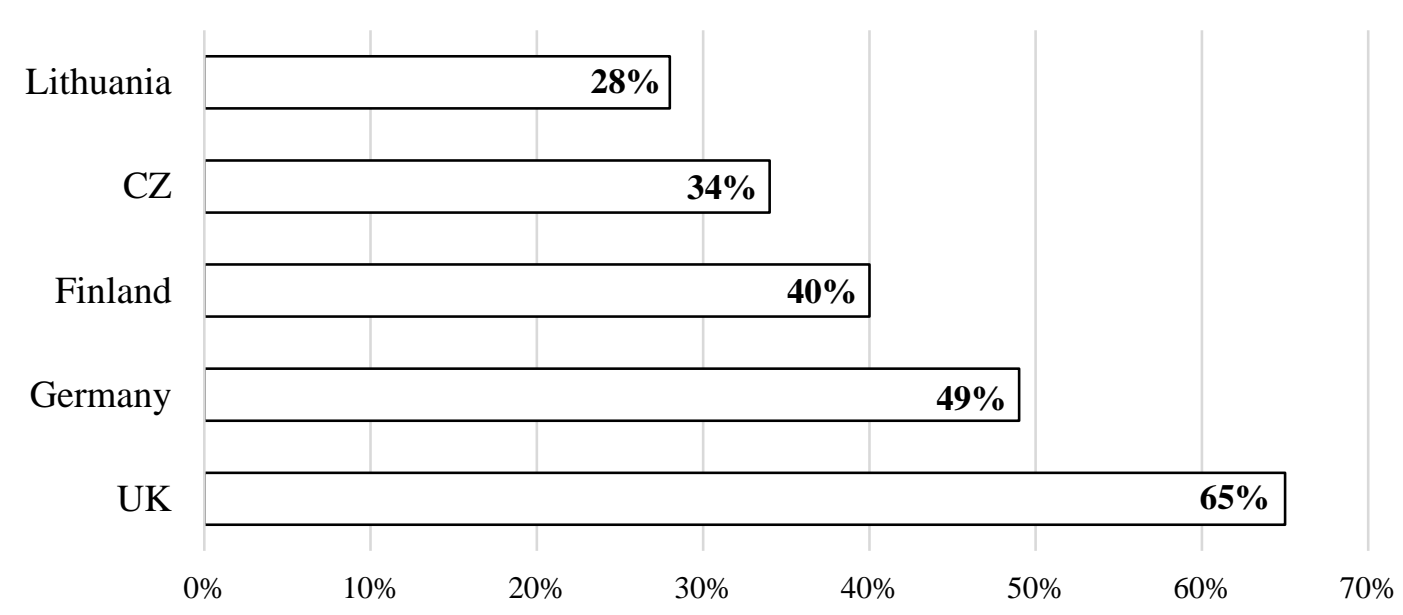

Fig. 2. Use of social media/networks by SMEs. Source: (Maršíková et al., 2019).

The future perspective of the use of digital skills in the position of HR was also evaluated by this survey. HR managers were those who were identified as one of the key groups influenced by digitalization in the past and in the near future. However, the respondents' answers show that HR managers, who are included in 10 selected occupations in the sector of Information and communication, professional, scientific and technical activities, demonstrated no change in ICT use during the last five years. 


\begin{tabular}{|c|c|c|c|c|}
\hline \multirow[b]{2}{*}{ Job title } & \multicolumn{2}{|c|}{ Last 5 years } & \multicolumn{2}{|c|}{ Next 5 years } \\
\hline & 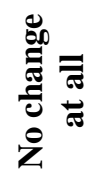 & 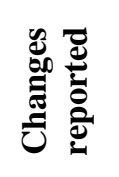 & 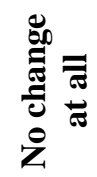 & 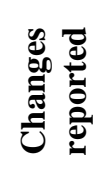 \\
\hline Finance managers & 8.1 & 91.9 & 2.9 & 97.1 \\
\hline Human resource managers & 16.7 & 83.3 & 20.0 & 80.0 \\
\hline
\end{tabular}

Tab. 5. Use of ICT in LAST and NEXT five years, by sector and occupation. Source: Authors based on (Curtarelli et al., 2016).

Also, it is quite surprising that they expect no changes at all in $20 \%$ of cases in the use of ICT in HR manager positions. For a comparison with HR professionals, the authors selected financial managers, where significantly more changes were reported in the last 5 years and also in the next 5 years (see Tab. 5).

\section{Discussion}

The findings from this survey demonstrate that the power of digital transformation is only beginning to emerge, and HR tends to be slightly late to the party of technology adoption. The Heretic's survey for Bain \& Company (2018) confirms that at least one in four enterprises still use manual or paper-based processes as the main way of delivering HR services. Moreover, $75 \%$ of respondents consider that their digital tools and technologies have not yet achieved their highest possible realization. Katolik Kovacevic and Cobovic's study (2017) emphasizes that currently only each sixth business uses digital technologies in their daily activities for education and human resource development. At the same time, a vast majority of tested companies (95\%) agree that digital technologies bring significant changes and fully or partially support the development of the human resource. In this regard, it is worth noting that the adoption of new technologies also requires more simplified and standardized processes, systems and data. The research provided by Mitrofanova et al. (2019) demonstrates the main challenges companies face when introducing new digital technologies in HR management. Among others, the complexity and heterogeneity of HR management processes, employees' resistance to revolutionary changes and a lack of systematic use of digital technologies in daily HR tasks were recognised. Moreover, only $35 \%$ of employers have already implemented an integrated system of automation of HR management.

Even though the new world of digital HR is developing rapidly, Stephan et al.'s research (2016) of digital HR's importance shows that each third company defines it as a very important priority and only $9 \%$ of enterprises believe they are fully ready for it. Some of the main obstacles in the process of successful digital transformation mentioned in the Oracle \& Research Now SSI (2018) study are legacy IT systems (53\%), acquiring new talents (49\%) and resistance to change within the company culture (42\%).

Another study of human value in the digital era (2017) conducted by Velthuijsen et al. emphasizes the increasing demand for higher education skillsets, such as social and creative intelligence. According to Molotkova et al. (2019) in the conditions of digitalization, the role of such soft skills as critical thinking, cognitive flexibility, complex problem solving, ability to learn, interaction skills and willingness to share knowledge is becoming more and more 
important. It is also worth noting that according to the Hackett Group HR Key Issues Study (2018) less than half of organizations (46\%) possess the resources and skills necessary for successful implementation of digital transformation strategy and changing the HR service delivery model.

According to the Patmore et al.'s research (2017) learning and development (51\%), performance management (45\%) and onboarding (44\%) are the areas organizations are looking to support digitally in the following period. At the same time, HR analytics is the biggest weakness of the organizations surveyed. The study conducted by Nankervis et al. (2019) states that big data (15\%), cloud technology (10\%) and mobile technologies (8\%) are not so popular and not likely to be actively used by HR practitioners in their daily work in the future. In particular, it leads to the need to develop greater awareness of HR professionals about the potential of current technologies and increase their motivation for developing new competencies. It should be noted that recruiting the right talent, using technology to improve collaboration and productivity, empowering managers to make decisions and using technology to improve HR processes are not yet well established and have the biggest potential for improvement (Oracle \& Research Now SSI, 2018). To effectively solve current business problems and support productive change, collaboration and leadership in the future, HR specialists need to be able to use integrated analytics and technology to improve decision-making and maximize their contribution to organizational success.

Several sets of data were used in the paper but only partial results are presented here, and the samples are limited in their scale and representativeness. Also, the literature review still has some gaps such as incomplete retrieval of the secondary data and literature review. The data from the European Digital Skills Survey (2016) were gathered in six EU member states and also data from the SHARPEN project were collected in five European regions in SMEs (2018). As a result, the findings of this study cannot be generalized beyond those countries and regions. It is also limited by the sample size defined as 7,800 employers. Additionally, the process of research has identified a difference in the opinions of experts, business leaders and HR professionals concerning the type of HR digital skills and competencies that will be vital for a successful digital transformation of the human resource management. These topical issues open space for authors to carry out further research in this area.

\section{Conclusion}

Digitalization represents a major challenge for employers, workers and public authorities, and the challenges need to be fully understood so that the most appropriate policy options can be identified to transform them into opportunities for all (Curtarelli, M. et al., 2016). The influence of digital technologies has an impact on competencies required in different jobs and changing the extent of their current use in workplaces. The paper aims to analyse how digitalization influences also competencies in HR and how digital skills are needed and used by HR managers. The findings in the paper based on the literature review and the presentation of selected findings of the European Digital Skills Survey (2016) showed an increasing demand for digital skills in many jobs in recent years. This trend is expected to continue growing due to the increasing number of jobs that require employees to use ICT and possess digital skills. 
The paper identifies the merits and demerits of digitalization in HR. In the case of jobs in HR, digital competencies are becoming more and more important, and the positions of HR managers were identified as those where the trend of growth in importance of digital skills will increase in the next five years. Not only using the Internet and working with computers but also social media implementation has become an essential part of HR.

\section{References}

Accenture. (2017). Digitally-powered HR. Retrieved August 26, 2019 from https://www.accenture.com/ acnmedia/accenture/conversionassets/dotcom/documents/global/pdf/dualpub 26/accenture-digital-hr-pov.pdf

Bokelberg, E., Dorai, C., Feinzig, S., Guenole, M., Lesser, E., Mertens, J., Raisbeck, L., Reyes, W., \& Steele, S. (2017). Extending expertise: How cognitive computing is transforming HR and the employee experience. Retrieved April 13, 2019 from https://www.ibm.com/downloads/cas/QVPR1K7D

Böhmová, L., \& Chudán, D. (2018). Analyzing Social Media Data for Recruiting Purposes. Acta Informatica Pragensia, 7(1), 4-21. doi: $10.18267 /$ j.aip.111

Brennen, J. S., \& Kreiss, D. (2016). Digitalization. In K.B. Jensen \& R.T. Craig (Ed.), The international encyclopedia of communication theory and philosophy (pp. 556-566). Chichester: Wiley Blackwell.

Cantoni, F., \& Mangia, G. (2019). Human Resource Management and Digitalization. Abingdon, New York, Torino: Routledge.

Crummenerl, C., Jacob, F., \& Funk, L. (2018). Now or never - HR's need to shape its own future. Retrieved August 25, 2019 from https://www.capgemini.com/consulting-de/wp-content/uploads/sites/32/2018/05/nowor-never-hrs-need-to-shape-capgemini-consulting.pdf

Curtarelli, M., Gualtieri, V., Shater Janatti, M., \& Donlevy, V. (2016). ICT for work: Digital skills in the workplace. Retrieved April 25, 2019 from https://ec.europa.eu/digital-single-market/en/news/ict-work-digitalskills-workplace

Diromauldo, T., Girimonte, F., \& Osle, H. (2018). The CHRO agenda: Enabling enterprise digital transformation takes center stage. Retrieved August 17, 2019 from https://www.thehackettgroup.com/elq-key-issues-hr1801/?leadSourceMostRecent=Social\%20Media\&leadSource=Social\%20Media\&campaignID=7013300000 12mj|AAA\&leadSourceDescription=HCKT\%20Download:\%20Key\%20Issues\%2018Q1HR1\%20-\%20SM

European Round Table of Industrialists. (2017). Building and transforming skills for a digital world. Retrieved April 25, 2019 from https://www.ert.eu/document/building-and-transforming-skills-digital-world

Fenech, R., Baguant, P., \& Ivanov, D. (2019). The Changing Role of Human Resource Management in an Era of Digital Transformation. Journal of Management Information and Decision Sciences, 22(2), 166-175.

Galgali, P. (2017). Digital transformation and its impact on organization's Human Resource Management. Retrieved August 17, 2019 from

https://www.academia.edu/35595152/Digital Transformation and its Impact on Organizations Human R esource Management

Heric, M. (2018). HR's new digital mandate. Digital technologies have become essential for HR to engage top talent and add value to the business. Retrieved August 20, 2019 from https://www.bain.com/contentassets/3dea09cc27fd426abfb35f9caa0e97dc/bain brief hrs new digital mandate.pdf

Kagermann, H. (2015). Change through Digitization-Value Creation in the Age of Industry 4.0. In H. Albach, H. Meffert, A. Pinkwart \& R. Reichwald (Ed.), Management of Permanent Change (pp. 23-45). Wiesbaden: Springer Gabler. doi: 10.1007/978-3-658-05014-6 2

Katolik Kovacevic, A., \& Cobovic, M. (2017). Impact of Digital Technology in the Development of Human Resources. In U. Bacher, D. Barkovic, K. H. Dernoscheg, M. L. Maronic, B. Matic, \& B. Runzheimer (Eds.), Interdisciplinary Management Research XIII (pp. 312-326). Opatija: Josip Juraj Strossmayer Univ Osijek, Fac Econ Osijek, Postgraduate Doctoral Study Program Management, Hochschule Pforzheim Univ.

Lo, K., Macky, K., \& Pio, E. (2015). The HR competency requirements for strategic and functional HR practitioners. The International Journal of Human Resource Management, 26(18), 2308-2328. doi: $\underline{10.1080 / 09585192.2015 .1021827}$

Mangipudi, M. R., \& Vaidya, R. (2018). A study of digitalization in HRM and its Effectiveness in Execution of HR Strategies and Policies. Helix, 8(6), 4220-4222. doi: 10.29042/2018-4220-4222 
ManpowerGroup. (2017). Skills Revolution 2.0 Robots Need Not Apply: Human Solutions for the Skills Revolution. Retrieved April 14, 2019 from https://www.manpowergroup.com/wps/wcm/connect/59db87a716c6-490d-ae70-1bd7a322c240/Robots Need Not Apply.pdf?MOD=AJPERES

Manuti, A., \& De Palma, P. D. (2018). Digital HR: a critical management approach to the digitalization of organization. Cham: Palgrave Macmillan.

Manyika, J., Lund, S., Chui, M., Bughin, J., Woetzel, J., Batra, P., Ko, R., \& Sanghvi, S. (2017). Jobs lost, jobs gained: Workforce transitions in a time of automation. Retrieved August 24, 2019 from https://www.mckinsey.com/ /media/McKinsey/Featured\%20Insights/Future\%20of\%20Organizations/What\% 20the\%20future\%20of\%20work\%20will\%20mean\%20for\%20jobs\%20skills\%20and\%20wages/MGl-JobsLost-Jobs-Gained-Report-December-6-2017.ashxmitr

Maršíková, K., Rajander, T., Clauss, A.-M., Medžiūnienè, I., Meschitti, V., Štichhauerová, E, Davies, J., Dulkè, D., Komulainen, R., Macháčková, V., Richter, M., Schumann, C.-A., Moš, O., \& Forkel, E. (2019). People management challenges for SMEs in five European regions: Spotlighting the (in)visible and the (in)formal and embedding SME HR issues firmly in the business and knowledge environment. Huddersfield: University of Huddersfield.

Maršíková, K., \& Mazurchenko, A. (2019). Digitalization: transforming the nature of HRM processes and HR professionals' competencies. In K. Antlová \& T. Semerádová (Eds.), Proceedings of the 14th International Conference Liberec Economic Forum (pp. 291-301). Liberec: Technical University of Liberec.

Mazzone, D. M. (2014). Digital or death: Digital transformation - The only choice for business to survive smash and counter. Mississauga: Smashbox Consulting.

Mitrofanova, E. A., Konovalova, V. G., \& Mitrofanova, A. E. (2019). Opportunities, Problems and Limitations of Digital Transformation of HR Management. In V. Mantulenko (Eds.), The European Proceedings of Social and Behavioural Sciences (pp. 1717-1727). Samara: Future Academy. doi: 10.15405/epsbs.2019.03.174

Molotkova, N. V., Makeeva, M. N., \& Khazanova, D. L. (2019). Digitalized Personnel Management. In V. Mantulenko (Eds.), The European Proceedings of Social and Behavioural Sciences (pp. 757-767). Samara: Future Academy. doi: 10.15405/epsbs.2019.03.75

Nankervis, A., Connell, J., Cameron, R., Montague, A., \& Prikshat, V. (2019). 'Are We There Yet?' Australian HR Professionals and the Forth Industrial Revolution. Asia Pacific Journal of Human Resources, 1-17. doi: 10.1111/1744-7941.12245

Oracle \& Research Now SSI. (2018). Tomorrows' HR, today. Exploring the role of human resources in digital transformation. Retrieved August 17, 2019 from https://www.oracle.com/assets/digital-transformation-study5072799.pdf

Patmore, B., Somers, J., D'souza, D., Welch, D., \& Lawrence, J. (2017). Research report: The State of Digital HR in 2017. Retrieved April 13, 2019 from https://www.hrzone.com/resources/the-state-of-digital-hr-in-2017

Paychex. (2018). Paychex Pulse of HR Survey: Tech Adoption Continues to Build HR's Strategic Skills. Retrieved April 14, 2019 from https://www.paychex.com/secure/whitepapers/hr-pulse-2018

Pieriegud, J. (2016). Cyfryzacja gospodarki i społeczeństwa - wymiar globalny, europejski i krajowy. In J. Gajewski, W. Paprocki \& J. Pieriegud (Ed.), Cyfryzacja gospodarki i społeczeństwa. Szanse i wyzwania dla sektorów infrastrukturalnych (pp. 11-38). Gdańsk: Instytut Badań nad Gospodarką Rynkową, Gdańska Akademia Bankowa.

Rastgoo, P. (2016). The Role of Human Resources Competency in Improving the Manager Performance. Acta Universitatis Agriculturae et Silviculturae Mendelianae Brunensis, 64(1), 341-350. doi: 10.11118/actaun201664010341

Sorko, S. R., Rabel, D., \& Richter, H. M. (2016). The future of employment - challenges in human resources through digitalization. Naučni izvestiâ na Naučno-tehničeskiâ s"ûz po mašinostroene, 24(2), 38-41.

Stephan, M., Uzawa S., Volini, E., Walsh, B., \& Yoshida, R. (2016). Digital HR: revolution, not evolution. In J. Bersin, B. Dollar, N. Wakefield, D. Mallon, L. Monck, J. Stempel \& S. Vijay (Eds.), Global Human Capital Trends 2016. The new organization: different by design (pp. 97-101). Deloitte University Press.

Stracke, C. M. (2011). Competences and Skills in the Digital Age: Competence Development, Modelling, and Standards for Human Resources Development. In E. Garcia-Barriocanal, Z. Cebeci, M. C. Okur \& A. Ozturk (Eds.), Proceedings of the 5th International Conference on Metadata and Semantic Research (pp. 34-46). Izmir: Springler Verlag. doi: 10.1007/978-3-642-24731-6 4

Ulrich, D., Brockbank, W., Kryscynski, D., Ulrich, M., \& Slade, J. (2016). 2016 HR Competency Model. Retrieved April 25, 2019 from http://www.apg.pt/downloads/file954 pt.pdf

Ulrich, D., \& Dulebohn, J. H. (2015). Are we there yet? What's next for HR? Human Resource Management Review, 25(2), 188-204. doi: 10.1016/j.hrmr.2015.01.004 
Velthuijsen, J. W., Van Tol, W., \& Hagen, A. (2017). Human value in the digital age. Retrieved April 13, 2019 from https://www.pwc.nl/nl/assets/documents/pwc-human-value-in-the-digital-age.pdffenech

Volini, E., Occean, P., Stephan, M., \& Walsh, B. (2017). Digital HR. Platforms, people, and work. In J. Schwartz, L. Collins, H. Stockton, D. Wagner D. \& Walsh B. (Ed.), Rewriting the rules for the digital age. 2017 Deloitte Global Human Capital Trends (pp. 87-92). Deloitte University Press.

Wellins, R. S., \& Sadjady, S. (2018). HR under pressure: felling behind in the race to transform. In E. Sinar, R. L. Ray, S. Wellins, Neal, S., A. L. Canwell, A. L. Abel, A. Popiela, J. Dettmann, L. Rolland, L. Collins \& T. Cotton (Ed.), The Global Leadership Forecast 2018 (pp. 50-51). Ernst \& Young.

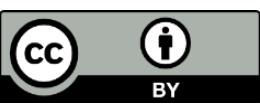

Copyright (c) 2019 by the author(s). Licensee University of Economics, Prague, Czech Republic. This article is an open access article distributed under the terms and conditions of the Creative Commons Attribution License (CC BY), which permits use, distribution and reproduction in any medium, provided the original publication is properly cited, see http://creativecommons.org/licenses/by/4.0/. No use, distribution or reproduction is permitted which does not comply with these terms.

The article has been reviewed. I Received: 31 August 2019 | Accepted: 3 November 2019

Academic Editor: Zdenek Smutny 
